\title{
Indicación de la situación hermenéutica que envuelve a la filosofía platónica
}

\section{Indication of hermeneutical situation enveloping the Platonic philosophy}

\author{
Alejandro, RoJAS JIMÉNEZ \\ Colegio MIT School Malaga \\ Alejandro@filosofiaenmalaga.net
}

Recibido: 08/07/2014

Aceptado: 01/05/2015

\section{Resumen}

Análisis de distintas situaciones hermenéuticas desde las que se ha leído a Platón, en busca de una lectura de Platón plegada a los textos salvada de las reformulaciones y esquemas con los que la tradición le ha ido dando forma a Aristocles hasta que éste se ha desvanecido en el juego de máscaras que él mismo inició, desapareciendo el personaje histórico (y los intereses y preocupaciones de su realidad vital) y tomando forma el Platón de la tradición occidental. No se busca desde luego en este trabajo restaurar a un Platón original e incontaminado, sino indicar la situación hermenéutica desde la cual nuestra situación actual nos permite una interpretación posible de los diálogos platónicos -digamos parafraseando a Ortega- a la altura de nuestro tiempo.

Palabras clave: Límite, bien, hermenéutica, principios, género.

\begin{abstract}
Analysis of different hermeneutical situations from which Plato was read, looking for a reading of Plato folded texts and saved from reformulations and schemes with which the tradition has been shaping Aristocles until he has faded in the game of masks that he began; disappearing the historical character (and the interests and concerns of their real life) and Plato taking shape in the Western tradition. Certainly this paper not look to restore an original and uncontaminated Plato, but to indicate the hermeneutical situation from which our current situation allows a possible interpretation of Plato's dialogues - paraphrasing Ortega- at the height of our time.
\end{abstract}

Keywords: Limit, Good, hermeneutics, principles, type. 


\section{Introducción: Platón, Aristóteles y el tercer hombre}

\section{I.1. La lectura aristotélica del platonismo}

Una de las críticas más contundentes al platonismo es aquella que aparece en la Met. III, 2 997b 5, en la que el estagirita parece criticar las ideas platónicas calificándolas como "sensibles eternos". ${ }^{1}$ La iconografia ${ }^{2}$ ha sabido representar esta crítica a la ontologización de las ideas oponiendo a un Platón que señala el cielo un Aristóteles que, con la palma de la mano, señala la Tierra con un gesto firme y decidido. Si le ponemos palabras a la imagen, éstas serían: no hace falta que exista un modelo ("exemplum speciem") porque se pueden encontrar las causas y los principios "en" las cosas sensibles; a las que llega a calificar con mordacidad como las únicas sustancias reconocidas por todos. ${ }^{4}$

La pregunta hermenéutica que parece haber aquí detrás de esta crítica es: ¿cómo es posible que aquello por lo que algo es lo que es no resida en el objeto, sino fuera de él? Quiero mostrarles en esta introducción, cómo y dónde llega a gestarse esta pregunta, hasta hacerles ver que Platón no es aquel sobre el que dicha pregunta recae de un modo demoledor, sino aquel que guió e impulsó esta cuestión.

\section{I.2. La imprescindible y olvidada figura de Eudoxo}

Cuando Aristóteles ingresa en la Academia en el 367/366aC ${ }^{5}$, donde permanecerá 20 años, ${ }^{6}$ Platón no estaba en la Academia porque se encontraba en Sicilia donde permaneció hasta el $364^{7}$. Aristóteles no recibió pues su formación inicial dentro de la Academia ${ }^{8}$ directamente de Platón, sino de los platónicos ${ }^{9}$; siendo seguramente el personaje más prominente de aquellos tiempos Eudoxo ${ }^{10}$.

Quiero detenerme en este tercer hombre ${ }^{11}$, Eudoxo. En su ausencia, el filósofo aventajado "enseñaba" en la Academia por supuesto y entre otras cosas la decisiva técnica fi-

\footnotetext{
${ }^{1}$ Met. III, 2, 997 b. $5-12$.

${ }^{2}$ Cfr., La scuola di Atene de Rafael Sanzio, pintura al fresco 500x770, 1510-151.

${ }^{3}$ Met., VII 9, 1034a1-10.

${ }^{4}$ Cfr., Met., VIII 1, 1042b 24-25.

${ }^{5}$ Cfr., Reale, G., Introducción a Aristóteles, Herder 2003, p. 13.

6 "Aristóteles se encontró con Platón a la edad de 17 años y permaneció en la escuela de éste durante 20", Diógenes laercio, V, 9.

${ }^{7}$ Ibid., p. 14.

${ }^{8}$ Aunque todo apunta a que ya estaba familiarizado con las doctrinas platónicas antes de ingresar.

${ }^{9}$ Espeusipo, Filipo de Opunte, Erasto, Corisco...

${ }^{10}$ Para un acercamiento a la figura de Eudoxo: Lloyd, G.E.R., Early Greek Science: Thales to Aristotle, Norton, Nueva York, 1970.

${ }^{11}$ Se trata evidentemente de un juego de palabras. El título el tercer hombre hace referencia por un lado y sobre todo al conocido como argumento del tercer hombre, pero también aunque indirectamente a esta figura olvidada generalmente por la tradición y sin embargo vital en el origen de aquel argumento.
} 
losófica propia de la escuela. Es decir, la dialéctica. Los académicos, amantes del diálogo filosófico en el que los formaba su maestro, no se dedicaban a la enseñanza de una teoría compacta que funcionara al modo de una doctrina inamovible. Habían sido formados, con más tenacidad que en ninguna otra cosa, en el diálogo filosófico; en la técnica dialéctica. Este diálogo versaba desde luego sobre ciertos temas, que podríamos decir que constituyen el núcleo del platonismo, pero los diálogos no son sólo una forma hermosa de presentar una doctrina o teoría: la doctrina platónica sólo existe en forma de diálogo, y no en forma de cualquier tipo de diálogo, sino en forma de diálogo dialéctico.

$\mathrm{Y}$ en este punto difiero de la defensa de algunos estudiosos que sostienen que con el tiempo este diálogo va consolidándose en una doctrina que los platónicos asumirían sin cuestionar, ${ }^{12}$ y considero por el contrario que lo propio de los académicos (es la gran herencia de Sócrates de no dejarse seducir por ningún discurso, tampoco el aparentemente verdadero ${ }^{13}$ ) es fijarse en lo problemático. ${ }^{14} \mathrm{Y}$ así, el diálogo no deja de ser un ir revisando continuamente las propias doctrinas que parecían ir fraguando en los diálogos, ya que desde luego no sólo se trataba de fijarse en lo problemático de las demás teorías, sino especialmente y sobretodo de las propias consideraciones que van teniendo lugar en las propias discusiones dentro de la Academia. Considero pues que la "evolución" que se ve en los diálogos, y en el que se vuelven recurrentes ciertos temas, no es una "evolución"15 en la que sobrevive lo mejor de una doctrina que se va consolidando como tal, sino una evolución cuyo avance consiste en trazar

\footnotetext{
${ }^{12}$ La llamada teoría de las ideas de Platón es una teoría elaborada por estudiosos que la anhelan. Es cierto que desde la óptica del siglo XIx podría parecer a muchos (Nietzsche en este sentido sería uno de los filósofos del futuro que ya avisó de una manera pionera, y basándose en la lectura del Fedro, que no había que buscar nada sólido en los diálogos platónicos escritos) que si Platón no hubiera tenido (aunque sea de puertas para dentro, de modo misterioso y esotérico) una teoría de las ideas bien estructurada y pensada, entonces no podría ser considerado un filósofo de pleno derecho (cuando es a todas luces el primero de todos); pero desde una óptica actual, no hay ningún inconveniente (e incluso resulta enaltecedor del propio platonismo) afirmar que pueda haber filosofía sin sistema, y no porque sean días dorados para las razones poéticas, sino porque en la época actual la profundidad no se asocia ya necesariamente a un sistema, e incluso en algún sentido la profundidad, y aún más el afán de profundidad, parece sugerir la demolición o revisión continua de todo sistema. Pensadores como Platón puede que representen el inicio de una actitud que se repite después en Schelling o Heidegger, en Wittgenstein o Putnam: allí donde hay profundidad y deseo de saber, donde hay filosofía, a menudo hay más caminos de bosque (Holzwege) que monumentos ante los que arrodillarse (como apostillaría Nietzsche en $E l$ Crepúsculo de los ídolos).

${ }^{13}$ Filosofar es reconocer lo que en el discurso hay de aparente y sólo aparente verdad. Cfr., Sofista $215 \mathrm{ss}$.

${ }^{14}$ Por ello es importante resaltar que hay que ocuparse con seriedad del no ser (disperso por todas partes. Cfr. Sofista 260b), porque es lo que nos va permitir entender que debemos "avanzar discutiendo caso por caso" Sofista 259c.

${ }^{15}$ Más adelante comentaré la influencia distorsionadora que la idea de evolución ejerció en los intérpretes del siglo XIX a la hora de leer a Platón, obsesionados con encontrar el modo en el que las doctrinas iban superando las dificultades y evolucionando hacia una doctrina consolidada.
} 
círculos volviendo una y otra vez a lo que se creía sólido para cuestionarlo ${ }^{16}$ distinguiendo lo verosímil de lo verdadero $;{ }^{17} \mathrm{y}$ de este modo bien se podría decir que en lugar de avanzar el diálogo se va hundiendo en lo problemático quedando únicamente intacto el ejercicio del propio diálogo. ${ }^{18}$

El avance por ello resulta lento, ${ }^{19}$ tanto que no se vislumbra un final; ${ }^{20}$ ni Platón lo promete. Testimonio de ello dan los diálogos mismos. Estas palabras del propio Platón deben ser suficientemente clarificadoras al respecto de este camino tortuoso que parece amenazar con un final inalcanzable: "Coraje, Teeteto. Es necesario ir siempre hacia adelante, por poco que se avance," 21 "no nos desanimemos respecto de lo que aún nos falta".22

Estas dos citas de Platón pertenecen a un diálogo en el que intenta distinguir a los filósofos (platónicos) de los sofistas. Quiere señalar un aspecto positivo de su método dialéctico que nos distinga de los sofistas. Y este rasgo fundamental no consiste en ningún elenco cerrado de doctrinas sabidas, no consiste en ninguna teoría incuestionable acerca de las ideas o las Formas, sino que según Platón, un Platón ya maduro y sabio, lo que nos distingue es que buscamos detectar lo falso como procedimiento dialéctico que permite el avance lento en apariencia a veces inacabable. El amor a la verdad de la filosofía no es pues, al menos en la Academia de Platón, ningún amor a una teoría bien estructurada, sino el amor a filosofar que nos empuja a detectar lo falso de nuestras propias doctrinas. Buscar lo falso es pues la gran diferencia entre la técnica dialéctica y la técnica engañadora de los sofistas según señala el propio Platón. ${ }^{23}$ Sin duda, con Platón el aforismo socrático alcanza su mayor apogeo y culminación. ${ }^{24}$

\footnotetext{
${ }^{16}$ Revolviendo de arriba abajo todos los discursos que versan sobre el tema que buscamos. Cfr., Fedro 272c.

${ }^{17}$ Cfr., Fedro 273 d.

${ }^{18}$ Así, cuando por ejemplo se enfrenta a las cuestiones que amenazan con ridiculizar la esencia del carácter elevado de las ideas, es decir, cuando en el Parménides se ve empujado a defenderse de que existan ideas como la idea de Pelo o uña, en realidad no concluye nada, ni que existan ni que no existan. $\mathrm{Si}$ acaso concluye que debe practicarse más el entrenamiento dialéctico para llegar a salvar esas dificultades. El diálogo es pues lo único que siempre permanece intacto, incluso cuando él mismo parece demoler todo lo sólido. Precisamente, y esto lo veremos con cierta profundidad más adelante, lo único que podría amenazar al diálogo mismo es encontrar algo tan sublime sobre lo que quepa callar.

19 "no te extrañes de que el rodeo sea largo" Fedro 274a.

${ }^{20}$ Cfr., Sofista 261 b.

${ }^{21}$ Sofista $261 \mathrm{~b}$.

${ }^{22}$ Sofista 264b.

${ }^{23}$ Cfr., Sofista 264d-265a.

${ }^{24}$ Incluso me atrevería a decir que efectivamente lo que distingue a la filosofía es esta búsqueda de lo falso. No se trata de rechazar la búsqueda de la verdad, sino de entenderla como una búsqueda en la que el avance consiste en ir depurando lo falso, pero no en ir verificando lo verdadero. La crítica a la que el positivismo somete a la filosofía es injusta y desatinada. La filosofía sólo es posible como campo de batalla (que no tiene porqué tener la connotación negativa que le da Comte) donde la revisión nunca cesa.
} 
El Sofista, en el que se aclaran estas cuestiones sobre el método que les acabo de resaltar, ha sido a veces relegado por la tradición, precisamente porque se enfatiza el método sobre la doctrina. Pero lo que resulta interesante es que el Sofista no fue escrito para los extranjeros, que no conocían el método, sino muy posiblemente para los propios académicos, pues se había producido un acontecimiento singular en la Academia que amenazaba con difuminar la distinción entre filósofos y sofistas.

La llegada de Aristóteles a la Academia coincide con el inicio de un movimiento de revisión crítica que los críticos han analizado a partir de Sobre las ideas y Parménides. ${ }^{25}$ Eudoxo se había convertido en un defensor de la inmanencia de las ideas a partir de la idea de mezcla, cuyo uso había sido masivo entre los pluralistas. Si bien, Eudoxo pretendía recurrir a esta idea de mezcla para resolver uno de los más interesantes y complejos problemas del platonismo: ¿cómo puede ser que sea lo que está separado causa de las cosas?26 Eudoxo observa que la forma, una y simple, no puede explicar la multiplicidad, y considera que hay que sacar a las formas de su aislamiento. La tesis propuesta por Eudoxo es la siguiente: las ideas se mezclan con lo sensible. ${ }^{27}$ Es una tesis que recupera la vieja idea de las homeomerías de Anaxágoras, y que corregirá Platón en el Filebo (donde reinterpreta el significado de la mezcla). Pero antes de esto, aparece en escena el joven Aristóteles respondiendo a Eudoxo de una manera contundente: señalando la imposibilidad de la mezcla.$^{28}$ Aristóteles parece trazar un argumento que el propio Platón ${ }^{29}$ recogerá a su vuelta en el Parménides y que se conoce en la tradición filosófica como el argumento del tercer hombre ${ }^{30}$.

En sus diálogos Platón no utiliza la idea de hombre, pero se conoce este argumento como el argumento del tercer hombre porque Aristóteles sí lo hará en repetidas ocasiones: Met. 990b, 991a, 1932a, 1059b y 1079a. En el Parménides, en el que aparece Aristóteles, Platón recoge la posición aristotélica en torno a esta discusión bajo una pregunta que el ateniense formula como sigue ¿cuál es la relación que hay entre

\footnotetext{
${ }^{25}$ Cfr., BerTi , E., La filosofía del primo Aristotele, Padua, 1962, pp. 186-249.

26 "este filósofo creyó poder resolver la aporía básica de la doctrina platónica de las ideas, que consiste en la dificultad de conciliar los dos caracteres esenciales de las mismas, es decir, el ser separadas y al mismo tiempo causa de las cosas" Introducción a Aristóteles, op. cit., p. 25.

${ }^{27}$ Cfr., Met., I, 991a 14.

${ }^{28}$ Se suele hablar de Aristóteles como un crítico de Platón, y de Eudoxo como un platónico, pero en muchos sentidos la respuesta aristotélica es mucho más acorde con el platonismo que la tesis de la mezcla propuesta por Eudoxo.

${ }^{29}$ Cfr., Parm. 131e-132b. 132c-133a.

${ }^{30}$ Siguiendo la definición clásica de Alejandro de Afrodisia: si lo que es predicado con verdad de varias cosas tiene también una existencia separada fuera de las cosas de las cuales se predica, existe un hombre en sí, porque el hombre se predica con verdad de los múltiples hombres particulares, y al mismo tiempo es diferente de los hombres particulares. Pero entonces es preciso un tercer hombre fuera del hombre particular y de la idea. Pero, en este caso, habrá también un cuarto, que se predicará del tercero, de la idea y de los hombres particulares, y lo mismo un quinto, y así sucesivamente al infinito.
} 
la unidad de la forma (la idea) y la multiplicidad de los particulares (sensibles)? ${ }^{31} \mathrm{Si}$ Eudoxo decía que se mezclaban, Aristóteles expone el argumento del tercer hombre para mostrar dialécticamente que no puede explicarse la relación entre Formas y particulares porque siempre surge el problema de la semejanza ${ }^{32}$ que vuelve cualquier solución prevista paralógica.

\section{I.3. El origen prearistotélico ${ }^{33}$ del conocido como el argumento del tercer hombre}

Quiero señalar a continuación que el argumento del tercer hombre no aparece por primera vez, ni sólo, en el Parmenides ${ }^{34}$. Se podría mencionar por ejemplo que había aparecido ya antes al menos en la República 597c, y después al menos en el Timeo 31a. Recojo aquí su aparición en la República:

"No ha hecho [Dios] más que una cama por naturaleza, que es la cama esencial. Jamás ha producido ni dos ni muchas, ni nunca las producirá.

¿Por qué razón?- dijo

Porque si hiciese siquiera dos, aparecería una tercera -dije- cuya idea sería común a las otras dos, y aquella sería la cama esencial"

Este extracto resulta muy interesante pues su datación se ha fijado en torno al $370^{35}$, justo antes de irse a Sicilia. Con ello, lo que me interesa resaltar es que Eudoxo no había pues detectado un problema del que Platón no tuviera noticia, sino que Platón mismo estaba dando vueltas a estas cuestiones. A mí me parece que la secuencia debió ser la siguiente: Platón descubre un problema que Eudoxo pretende resolver siendo corregido por Aristóteles. ${ }^{36}$ Si esto es así, de ningún modo la formulación de

\footnotetext{
${ }^{31}$ Cfr., Parm. 133a ss.

32 tiene que existir una tercera entidad ("el tercer hombre") que abarque el aspecto común entre la cosa concreta y la Idea correspondiente

${ }^{33}$ No pretendo a continuación ningún análisis exhaustivo del origen del argumento, sino sólo señalar que su origen es pre-aristotélico, y que era conocido por Platón desde temprano. Algunos, como TAYLOR, A.E., The Parmenides of Plato, Oxford Clarendon Press, London, 1934, pp. 21-23, señalan por ejemplo un origen megárico. Entre quienes defienden un origen aristotélico mencionaré al menos el trabajo de Ross, D., Aristoteles's Metaphysics, vol I, Oxford, London, 1924, pp. 194-6. Si bien, para un estudio actualizado de la cuestión se recomiendan Vlastos, G., "Plato's Third Man Argument (Parm. 132 a-b)", Philosophical Quaterly 7 (1969), pp. 189-301, y en confrontación con Vlastos y como prueba de la polémica y discusión actual al respecto Teloh-Louzecky, "Plato's Third Man Argument", Phronesis 17-1(1972), 80-94.

${ }^{34} \mathrm{Al}$ respecto de la idea de grandeza. Cfr., Parm., 132 a-b.

${ }^{35}$ Cfr., CAndel, M., Introducción, en Platon, La República, Austral, 2000, p. 14.

${ }^{36}$ En Sobre las Ideas, una obra perdida para nosotros pero reconstruida a partir de los comentarios de Alejandro de Afrodisia a Met. I 9 [Alexander Aphrodisiensis. "In Aristotelis Metaphysica Commentaria". en: Hayduck, M., (Ed). Commentaria in Aristotelem Graeca. Berlin: Reimer, 1891. v. 1, p. 79-89; 9798.], Aristóteles habría desarrollado su respuesta antes de que Platón diera la suya propia en el Filebo.
} 
aquella pregunta puede ser antiplatónica, ni siquiera aunque la respuesta fuera demoledora para el platonismo, y ello por dos razones que ya hemos recogido: por un lado porque lo propio del platonismo, tal y como se ha defendido anteriormente, no es la cerrazón a una doctrina sino la búsqueda incesable de lo problemático en un intento apasionado por detectar lo falso, y en segundo lugar porque se trata de un problema que tiene su origen en el mismo Platón, que lo plantea antes de irse a Sicilia.

\section{I.4. La posición de Platón, tras su regreso a la Academia}

La posición de Platón al respecto de la discusión mantenida entre Aristóteles y Eudoxo se puede leer en el Parménides, el Sofista y el Filebo. Y se puede ver bien que el papel de Eudoxo es esporádico, representa una mala respuesta ante una gran pregunta. Su mérito consiste sobretodo en haber provocado que Aristóteles entrara a la filosofía por la puerta grande.

Lo primero que hay que recalcar es que el problema de la semejanza surge cuando intentamos pensar las ideas en relación con el mundo. ${ }^{37}$ Antes del Parménides Platón intenta sin éxito, como hace notar Aristóteles a Eudoxo, pensar/entender de distintos modos esta relación entre las ideas (Formas) y la multiplicidad sensible: mímesis $^{38}$ (imitación; lo sensible imita lo inteligible), methexis ${ }^{39}$ (participación; es "en parte"40 lo inteligible), koinonía ${ }^{41}$ (comunidad; relación de causa-efecto) y parousía ${ }^{42}$ (presencia; lo inteligible está de algún modo presente en lo sensible).

La solución platónica será encontrar un principio que dé razón de la imperfección sensible. Tal cosa es lo que hace Platón en el Filebo donde argumenta que no existe pues sólo un principio de unidad, sino también un principio de división; el Uno y la Díada. Pero antes de dar esta solución en el Filebo, lo que hay es desconcierto en la Academia; de la que se encontraba ausente Platón. En el Parménides, escrito a su vuelta de Sicilia, ${ }^{43}$ esto es, después del texto de la República que he recogido, Platón expone la discusión reconociendo que ninguna de sus soluciones había sido suficiente para hacer frente al problema que trae la idea de semejanza. Y así, le da la razón a Aristóteles en su discusión con Eudoxo ${ }^{44}$ al respecto de un problema del que Platón, antes de irse de viaje, había advertido a la hora de entender el papel causal de

\footnotetext{
${ }^{37}$ Cfr. Parm. 130 e-131 a.

${ }^{38}$ Criticada en el Sofista cfr. Sofista 234 b y en el Parm. $132 \mathrm{~d}$

${ }^{39}$ Banquete 212a, Fedón 100c, y criticada en Parm. 131ab.

${ }^{40}$ Para una profundización en la idea de participación aquí vagamente expresada se recomienda el trabajo de del Barco, J.L, Platón. Teoría de las ideas, Edinford, 1991, especialmente la tercera parte: participación y unificación ideal.

${ }^{41}$ Fedón 100d.

${ }^{42}$ Fedón 100d.

${ }^{43}$ Recordemos que el Parménides fue escrito alrededor del 368aC.

${ }^{44}$ Es la tesis de Reale, G., en Introducción a Aristóteles, op. cit., pp- 25-6.
} 
las ideas una vez que salen a la luz los problemas inherentes a la idea de semejanza entre cosas y formas. ${ }^{45}$

Ahora bien, según Platón, la falta de una respuesta eficaz al problema de la semejanza se debe sólo a la inexperiencia de los interlocutores y a su necesidad de ejercitarse más en la dialéctica. ${ }^{46} \mathrm{Da}$ a entender que él tiene una solución (que es la que he dicho que desarrollará en el Filebo). Y sin embargo, la pospone, porque le urge que no se olvide que lo propio del platonismo no es salvar una supuesta doctrina.

Al dejar el problema sin solución deja que reine el desconcierto en la Academia y que la siguiente cuestión se convierta en hiriente ¿qué distinguiría al filósofo del sofista si no hubiera solución? Como quiera que el filósofo se distingue del sofista incluso cuando no es capaz de encontrar una solución, Platón escribe el Sofista, en el que aclara que más importante que dar una respuesta lo es advertir que la diferencia entre estos y los filósofos dialécticos es que sólo los filósofos buscan detectar lo falso para no proclamar una falsa sabiduría. En el Sofista, es lo que a mí me interesa resaltar, la filosofía (el platonismo) quedaría salvada de la aparente crítica demoledora aún cuando no hubiera una solución. ${ }^{47}$

Pero el caso es que el filósofo debe aspirar a encontrar la solución. Y Platón, aunque la pospone, no la elude: propone su solución en el Filebo al referirse a dos principios (uno de indeterminación, material) y otro de determinación (formal). Incluso cabría encontrar en este diálogo una versión previa de lo que más tarde será la teoría de la causalidad aristotélica ${ }^{48} \mathrm{Y}$ sin embargo, en lugar de mostrar a Aristóteles como buen platónico ${ }^{49}$ que llevó con éxito la discusión platónica más allá de su maestro, ${ }^{50}$ la tradición nos ha legado la imagen de una oposición radical entre ambos. La iconografía aludida y la crítica aristotélica al platonismo que figura en el libro II de la

\footnotetext{
${ }^{45}$ Cfr., Sharvy, R., "Plato's Causal Logic and the Third Man Argument", Nous XX, 4 (1986), 507-530.

${ }^{46}$ Cfr., Parm. 135, c-d.

${ }^{47}$ Es interesante llamar la atención sobre el hecho de que, en concordancia con esto que comento de que pudiera no ser tan importante encontrar una solución, existió un platonismo inclinado al escepticismo en la Academia Media. Mi posición aquí no es tan extrema: defiendo la idea de que la dialéctica es fundamentalmente un método, y no un "sistema" de la verdad. Y aunque hay pasajes como Fedón, 85c donde es muy firme a la hora de enfatizar que con la dialéctica alcanzamos hitos difíciles de refutar, realzándose su potencia epistémica, esto no impide poner el énfasis en que estamos ante un método heurístico que por su carácter dia-léctico (los interlocutores tienen que ir cada vez poniéndose de acuerdo) no puede convertirse en "ciencia universal", sino en una suerte de eterno work-in-progress. Y ello en contra del intento de Porfirio.

${ }^{48}$ Cfr., RoJas, A., "De la Transformation der Philosophie y la recuperación de una comprensión del consenso ligada a la experiencia originaria del diálogo platónico-socrático", en Claridades 5 (2013), 43-58, p. 53. Y RoJas, A., "El bien y la intelección según Platón”, Thémata 50 (2014), 37-67.

${ }^{49}$ Cfr., Diógenes Laercio, V, 1.

${ }^{50}$ Por cierto, no menos se enfrentaron al maestro el resto de platónicos. Y es que lo platónico no era repetir, sino sumarse al diálogo, continuarlo.
} 
Metafísica han confundido a muchos filósofos (críticos con el platonismo) respecto de la auténtica filosofía de Platón.

\section{I.5. Avance de la tesis}

En el Filebo Platón va a recuperar la idea de mezcla ${ }^{51}$ que había utilizado Eudoxo, en un gesto que vuelve una vez más a demostrar hasta qué punto el Filebo es una respuesta relacionada con aquella discusión. Pero Platón la va a pensar de distinta manera, no ya como la mezcla de ideas en sí, no como la mezcla de lo que está entremezclado, sino que mezcla tiene aquí el sentido de combinación. La química moderna distingue entre mezcla y combinación para matizar la diferencia entre la que es arbitraria y la que resulta de una ley. Pues bien, esta es la novedad del Filebo, haber hecho hincapié en los principios de la combinación. Las ideas están combinadas con las cosas, y ello siguiendo cuatro principios o géneros que se corresponden con lo que después serán las cuatro causas aristotélicas.

El encargado de realizar dicha combinación en "el universo platónico" es el Demiurgo. ${ }^{52} \mathrm{Y}$ no lo hace de manera arbitraria, sino que se trata de una combinación que debe hacer Bien. La causa eficiente que representa el demiurgo está supeditada pues a una finalidad. La consideración de que la combinación está bien hecha es uno de los puntos en los que debemos insistir, porque a menudo malentendemos la imperfección del mundo sensible en el platonismo. Quiero decir: que las cosas no sean como debieran ser no debe entenderse en el sentido de que esta imperfección no sea buena. Hay algo bueno en su imperfección que es causa de la misma. Considerar al mundo sensible como el que no es bueno, en comparación con el ideal, no es -a mi juicio- justo con el platonismo, sino un añadido de la filosofía posterior que tiene su reformulación más lograda en la distinción agustiniana entre la ciudad terrena y la celestial. Pero para Platón este mundo "terrenal" no es "malo", ni siquiera podemos decir que sea una "mala" copia. Entender a Platón en su espíritu originario, pasa por entender ¿por qué es bueno el mundo si no es como debe ser (si no es el ideal)?

Para abordar esta cuestión es necesario analizar las principales situaciones hermenéuticas desde las que se ha leído a Platón, y ello porque quizás este análisis nos permita una lectura de Platón plegada a los textos salvada de las reformulaciones y esquemas con los que la tradición le ha ido dando forma a Aristocles hasta que éste se ha desvanecido en el juego de máscaras que él mismo inició, ${ }^{53}$ desapareciendo el per-

\footnotetext{
${ }^{51}$ Ya había avisado que se trataba de seguir pensando lo mismo, no de renunciar a la discusión del Parm.

${ }^{52}$ Cfr., Timeo 68 d 4-7.

53 "El único ausente era Platón” Luciano de Samósata, Relatos verídicos, II, 17. Citado en Mario VeGetTI, M., Platón, Gredos, Madrid, 2012, p. 79. En la misma página nos recuerda: "En sus diálogos, solo mencionaba una vez su propio nombre (aparte de la Apología, 38b, en donde Sócrates lo cita de entre aquellos que están dispuestos a contribuir al pago de una eventual sanción pecuniaria suya): y ello sucedía en el Fedón, para señalar justamente su ausencia, a causa de una indisposición, de la celda en la
} 
sonaje histórico (y sus intereses y preocupaciones reales) y tomando forma el Platón de la tradición occidental. La destrucción de la que habla Heidegger en 1922 referida a Aristóteles puede ser retomada para este caso que nos detiene. Decía Heidegger, a propósito de cómo se ha recibido a Aristóteles ${ }^{54}$, que "la teología cristiana, la "especulación filosófica" que se encuentra bajo su influencia, así como la antropología que la acompaña en contextos de este tipo, se expresan en categorías prestadas y ajenas a su propio ámbito ontológico". ${ }^{55}$ Con esta advertencia pretendía, no tanto destacar una actitud criticable ${ }^{56}$ sino hacernos tomar conciencia de la necesidad de preparar un "regreso" a las fuentes originarias que "asuma la tarea de deshacer el estado de interpretación heredado y dominante, de poner de manifiesto los motivos ocultos, de destapar las tendencias y las vías de interpretación no siempre explicitadas". ${ }^{57}$ Creo que este es también el punto por el que deberíamos comenzar nosotros aquí la tarea de desmontaje o destrucción anunciada.

\section{Aclaración metodológica: ¿Qué significa buscar el espíritu originario?}

Cuando se dice que se busca recuperar el espíritu originario, se debe aclarar que no se trata en ningún caso de conquistar el recinto privado de la mens auctoris. Lo que se persigue es cierta restauración de aquel fondo de sentido ${ }^{58}$ que, pensado como un contexto previamente dado (ein vorgegebener Zusammenhang ${ }^{59}$ ), hace posible la comprensión. Es decir, se trata de reconstruir el Fragehorizont ${ }^{60}$ de tal manera que nos permita entender lo entregado por traditio como respuesta a preguntas ${ }^{61}$ que ponen en relación las interpretaciones posibles. Esta pretensión hermenéutica busca en definitiva, dicho en pocas palabras, determinar narrativamente (récit) las cuestiones (Fragen) que indican (deuten) las interpretaciones (Deutungen) posibles. ${ }^{62}$

La búsqueda de este horizonte de comprensión sólo es posible desde la consideración asumida de que los conceptos "se refieren a un dónde y a un cuándo, a un aquí

que Sócrates mantuvo su postrera conversación e ingirió finalmente la cicuta)".

${ }^{54}$ Con el mismo propósito de recoger la Anzeige der hermeneutischen Situation.

${ }^{55}$ HeidegGer, M., Interpretaciones fenomenológicas sobre Aristóteles, Trotta, Madrid, 2002, p. 76.

${ }^{56}$ Diré que incluso, en tanto que lo propio de la filosofía es la búsqueda de la verdad, que estamos ante un claro ejercicio de filosofía auténtica.

${ }^{57}$ Interpretaciones fenomenológicas sobre Aristóteles, op. cit., 51.

${ }^{58}$ „Ihre Aufgabe überhaupt nicht ist, ein Verfahren des Verstehns zu entwickeln, sondern die Bedingungen aufzuklären, unter denen Verstehen geschieht.“ GADAMER, H-G ., WuM op. cit., p. 300.

${ }^{59}$ GaDAmER, H-G ., „Wort und Bild. So wahr, so seiend.“, GW VIII, 373-399, p. 397.

${ }^{60}$ GADAMER, H-G ., WuM op. cit., p. 375.

${ }^{61}$ Ibid., p. 368.

${ }^{62}$ Entender las interpretaciones (Deutungen) es a su vez un interpretar (deuten), y por ello la tarea del hermeneuta cuando se enfrenta a los textos traídos por la tradición puede ser calificada como ein Deuten deuten. Cfr., Gadamer, H-G ., "Zur Fragwürdigkeit des ästhetischen Bewusstseins", en Pareyson, L., (Ed.), II giudizio estético. Atti del simposio di estética, Padua, 1958, pp.14-23. 
o a un allí. ${ }^{93}$ Pero a diferencia de la línea historicista, que abandona la búsqueda de la verdad para limitarse a afirmar la relatividad e incluso la inconmensurabilidad ${ }^{64}$ de las opiniones (olvidando la historicidad que al historicismo le es propia), la hermenéutica por su parte hace de la verdad su tarea e intenta esclarecer el contexto o tradición dentro del cual (Heidegger lo llegará a designar como Lichtung ${ }^{65}$ ) los conceptos pueden ser comprendidos. Y así, mientras que para el historicismo la conciencia histórica conlleva la renuncia a la búsqueda de la verdad, para la hermenéutica actual, de corte heideggeriano, la pretensión es la de una comprensión más adecuada de los textos del pasado histórico en función de una rememoración $\left(\right.$ Andenken $\left.^{66}\right)$ que nos permita volver a pensar los conceptos en el contexto de sentido donde fueron gestados. Y esto puede ser expresado utilizando el término de ajuste.

Dicho término, el de ajuste, está siendo pensado aquí en el sentido en el que lo emplea Heidegger en su comentario a Anaximandro. Allí habla del ajuste (Fug) y el desajuste $(U n f u g)^{67}$ entre el pensamiento y el destino. Arturo Leyte y Helena Cortés, en la versión castellana, traducen así una de las citas principales de dicho comentario en el que aparece el sentido fundamental de este Fug al que nos referimos: "a lo largo del uso; en efecto, dejan que tenga lugar ajuste y atención mutua (en la reparación) del des-ajuste" ${ }^{98}$.

De Fug obtenemos Fuge, que significa construir ajustándose a determinadas reglas una pieza musical. Famosa es por ejemplo la Große Fuge op. 133 B-Dur de Ludwig van Beethoven. Según Heidegger los pensamientos y las ideas estarían ajustados de un modo análogo a la historia ${ }^{69}$ Por este motivo, comprender significa para el hermeneuta ir más allá de lo dicho en busca de ese horizonte al que lo dicho se ajusta. ${ }^{70} \mathrm{El}$ historicista sospecha por este motivo del hermeneuta, porque esto lo ve como una concesión a la subjetividad, especialmente porque cabe esperar que no

\footnotetext{
${ }^{63}$ Toulmin, S., Regreso a la razón. El debate entre la racionalidad y la experiencia y las prácticas personales en el mundo contemporáneo, Península, Barcelona, 2003, p. 36.

64 "una discusión racional y fructífera sólo resulta posible si los participantes comparten un marco conceptual común de asunciones básicas o, al menos, si están de acuerdo en tal marco conceptual para los propósitos de la discusión" Popper, K., The Myth of the Framework. Routledge and Kegan Paul, Londres, 1994, p. 34-35.

65 "el término Lichtung sustituye al término Welt, y el término Existenz al término Da-sein" ChozA, J., "Lectura de la carta sobre el humanismo de Heidegger", Thémata 32, 2004, pp 37-82, p 52.

66 "Nach dieser Hinsicht wird das Denken im Sprung zum Andenken, nicht an Vergagenes, sondern an das Gewesene" Heidegger, M., Vom Wesen des Grundes, Vottorio Klostermann, Frankfurt am Maim, 1973, p 107.

${ }^{67}$ „entlang dem Brauch; gehören nämlich lassen sie Fug somit auch Ruch eines dem anderen (im Verwinden) des Un-Fugs“" Heidegger, M., „Der Spruch des Anaximander“, GA 5, p. 372.

${ }^{68}$ Cfr., Heidegger, M., (trad. Leyte, A., y Cortés, H.), Caminos de bosque, Alianza, Madrid, 1995.

${ }^{69}$ „die Geschichte des abendländischen Denkens ruht im Geschick des Seins.“ M. Heidegger, „Der Statz von Grund“, en GA 10, p. 111.

${ }^{70}$ „Das Verstehen ist selber nicht so mehr als eine Handlung der Subjektivität zu denken, sondern als Einrücken in ein Überlieferungsgeschehen“" GADAMER, H-G., WuM o.c., p.295.
} 
se encuentre ninguna confesión del autor en cuestión que lo ratifique. La noción de ajuste es distinta en el historicismo que en la hermenéutica: en un caso es "ajustarse" (en el sentido de limitarse) a los textos (a lo confesado), en el segundo punto se trata de ajustar el texto (lo dicho) al horizonte de comprensión del autor para aclarar lo dicho en función de lo no dicho como une vérité posible. ${ }^{71}$

Uno de los modos como la hermenéutica ha querido defender la posibilidad de este uso teórico más allá de las limitaciones de la textualidad ha sido distinguir entre pretensiones de validez. Y aquí hay que mencionar a uno de los hijos ilustres de la hermenéutica: Habermas sabe que es necesario poder garantizar cierto tipo de consenso racional en torno a ideas correctas e incorrectas, reconociendo que lo correcto se distingue de lo cierto en función de su pretensión de validez. Teniendo como condición la inteligibilidad, ambas están relacionadas con intenciones, vivencias de certeza y bases de experiencias distintas: $:^{72}$ una implica creer a alguien, la vivencia de esa certeza es puramente de fe y la base de esta experiencia es la interacción entre personas. La otra, la rectitud, implica estar convencido de algo, carece de certeza y no habría una base de experiencia destacable. El tipo de seguridad es por ello distinto: la rectitud extrae su fuerza de las razones, no de una realidad que se pueda sacar a la luz (objetividad de la certeza), siendo dichas razones suficientes para poder establecer un warranted assertibility. ${ }^{73}$

Lo dicho aquí debe bastar como justificación del paso siguiente que procedemos a realizar en esta investigación: conviene evaluar el ajuste entre los textos platónicos y el esquema de los universales con el que la escolástica presenta la relación entre Aristóteles y Platón, ya que dicha contextualización ha marcado decisivamente el modo como entendemos a Platón aún hoy. Sólo en este contexto "pervertido" (en el sentido de ser un espacio de sentido distinto del que se daba en el tiempo en el que fueron redactados los diálogos) cobra sentido presentar a Platón, por ejemplo, como un realista extremo y entender de un modo "fuerte" la separación entre los dos mundos. Debe llegar a observarse por el contrario en qué medida la separación debe ser de grado respecto de una sola realidad, y que el realismo extremo se fundamenta en una fallida comprensión del "en sí" (cuyas primeras apariciones se remontan al Hipias mayor ${ }^{74}$ ) por parte de la escolástica inicialmente. Debe llegarse a observar en resumidas cuentas que la comprensión posible de cierto Platón sólo puede tener sentido en un contexto distinto al de la propia gestación de los diálogos platónicos.

\footnotetext{
71 "C'est-á-dire de l'admission d'une vérité possible, de propositions de sens qui nous sont d'abord étrangères" Ricoeur, P., Soi-meme comme un autre, Éditions du Seuil, Paris, 1990, p. 336.

${ }^{72}$ Habermas, J., „Wahrheitstheorien“, en Fahrendbach H. (Ed.), Wirklichkeit und Reflexion, Neske, Pfullige, 1973, pp. 211-265.

${ }^{73}$ Martin, R.M., „Truth and its illicit Surrogates“, en Neue Hefte für Philosophie, 1972, H 2/3, p. 101.

${ }^{74}$ Sobre la idea de belleza en sí misma en función de la cual decimos de las cosas (la joven hermosa a la que por ejemplo se refiere Platón) son bellas. Cfr., Hip. Maior, 288a.
} 


\section{Dos mundos cada vez más separados}

Una vez realizadas las precisiones metodológicas podemos volver al punto en el que lo habíamos dejado. Habíamos finalizado el bloque I haciendo referencia a una separación drástica del mundo sensible y el mundo ideal que tenía, aludíamos, su origen en un contexto distinto del platónico. Ese contexto es el mundo medieval, el cual ya era en sí mismo un mundo muy distinto del heleno, y en donde la separación de los mundos sensible e inteligible, aún apoyándose en las viejas ideas, encontraba un suelo fecundo donde podría extremarse. Por eso es necesario, y la importancia del Bloque II no es otra que la de advertir sobre esta necesidad, deconstruir en primer lugar el modo como la tradición nos ha legado la crítica aristotélica al platonismo.

\section{III.1. El contexto "perverso": el problema de los universales como un problema del siglo XII ${ }^{75}$}

Lo primero que hay que decir del problema de los universales es que no es un problema platónico ni aristotélico, ${ }^{76}$ sino que tiene su origen en el siglo XII a propósito de la introducción de Porfirio a las Categorías de Aristóteles; ${ }^{77}$ con la paradoja conocida de que Porfirio no hablaba de "universales", sino de quinque voces ${ }^{78}$ siendo el comentario de Boeccio ${ }^{79}$ en su In Isagogen Porphyrii commenta el que impulsa la controversia de los universales al dar a entender que una cosa puede ser a la vez singular y universal, ${ }^{80} \mathrm{y}$ es esto lo que van a reivindicar, rechazar o reformular las "sectas" del siglo XII: los realistas (cabrá distinguir entre realistas extremos y moderados), los nominalistas (para los que el universal es flatus vocis ya que nihil

\footnotetext{
${ }^{75}$ No es posible ni se pretende realizar a continuación un estudio del problema de los universales en profundidad, pues algo así merecería posiblemente un trabajo dedicado exclusivamente a ese tema. Mi intención a continuación es más bien mostrar el contexto en el que llega a ser posible el problema de los universales un problema como tal, y distinguirlo del contexto platónico, donde no juega un papel principal en rigor dicha problematicidad.

${ }^{76}$ Platón estaba desaparecido mayoritariamente, y de Aristóteles sólo habían sobrevivido las Categorías y De interpretatione. La Isagoge posiblemente sólo pudo leerse a través de los comentarios y monografías lógicas de Boecio.

${ }^{77}$ Isagoge, 1.

${ }^{78}$ Cinco vocales (con el inconveniente de que no se puede interpretar aún que estemos ante una tesis vocalista; quizás por ello conviniera pasarlo a nuestra lengua como cinco denominaciones) y que son Género, especie, diferencia, propio y accidente.

79 “es con Boecio y él sólo como los medievales han tenido los datos filosóficos de la Antigüedad y de la Antigüedad tardía. Es por él por quienes ellos han podido conocer algunas tesis centrales de la crítica aristotélica de Platón en una época en la que ignoraban casi todo del debate que les había opuesto" DE Rivera, A., El problema de los universales, Malpe, Madrid, 2013, 152.

80 "es el mismo sujeto quien, de una primera manera, es universal cuando es pensado y, de otra manera distinta, singular cuando es sentido en las cosas en las que tiene su ser" BoEcio, In Porph., I, 11, ed. S. Brandt, 167, 3-7.
} 
est praeter individuum) y los conceptualistas (que consideran que el universal es un conceptus mentis abstraído de la realidad singular). Bien entendido que un estudio en profundidad revelaría muchos matices dentro de cada uno de estos bloques.

Debe llamarse la atención sobre el hecho de que el problema de fondo era que Aristóteles no fue claro. En unos sitios parece defender la tesis de que las ideas las elabora el entendimiento ${ }^{81}$ pero existen algunos pasajes que dan a entender por el contrario que también él atribuía cierta realidad a los universales. ${ }^{82}$ En esta época existía el inconveniente de que no se tenían todas las obras, si bien el problema se complica si echamos un vistazo al conjunto de éstas. Esta ambigüedad es la causa de la disputa escolástica. Pero no fue en rigor, he de insistir, un problema que discutieran Platón y Aristóteles, sino un problema entre escolásticos, donde ambos pensadores eran aún bastantes desconocidos.

Dentro de estos escolásticos el realismo extremo, ${ }^{83}$ según el cual las ideas universales (como la idea de caballo o de fuego) existen realmente en el mismo sentido en el que decimos que las cosas sensibles existen (los caballos, el fuego...) fue defendido por sólo unos casos contados, de entre quienes cabe destacar a Guillermo de Champeaux, el abad de la abadía de San Víctor, quien parece por otro lado que relativamente pronto, según cuenta Abelardo ${ }^{84}$ se vería convencido de que esta posición no era defendible. La filosofía de Platón llega a ser considerara como una suerte de realismo extremo y caricaturesco en una discusión provocada por un comentario a un texto de Aristóteles ${ }^{85}$ en la que Platón sufre la desavenencia de convertirse en representante de un realismo que él nunca ha defendido explícitamente; quedando tergiversado y marcado el modo como entiende a Platón parte de la filosofía medieval, moderna y contemporánea.

No se trata tanto de que no sea posible interpretar a Platón como un realista extremo, sino de que el contexto o situación hermenéutica dentro de la cual Platón puede llegar a ser pensado como un realista extremo, es el contexto de una discusión ajena al propio Platón. Y así, si en el Fedón quedaba efectivamente dicho que las formas existían, ${ }^{86}$ ni siquiera aquí se decía explícitamente que existían separadas. Me parece mucho más aceptable la interpretación realista de los Melidunenses de Múnich, que puede dar lugar a una teoría de la indiferencia ${ }^{87}$ según la cual el universal no es una

\footnotetext{
${ }^{81}$ Cfr., Categorias 2, 1a 20-22.

${ }^{82}$ Cfr., Met., VII 7, 1032 b1.

${ }^{83}$ Es decir, no sólo el reconocimiento de la división que se fija por primera vez en el Fedón (Cfr., Guthrie, W.K.C., A History of Greek Philosophy, Cambridge University Press, 1975, IV, 359.), sino de su separación, según la cual las ideas no sólo son inmutables, uniformes y simples -a diferencia del mundo sensible-, sino cosas que existen separadas del mundo sensible.

${ }^{84}$ Cfr., Hist. Calam., 2.

${ }^{85}$ Cfr., Isagoge, 6.

${ }^{86}$ Cfr., Fedón, 102 b.

${ }^{87}$ Que Schelling parece recuperar posteriormente. Véanse por ejemplo las páginas 28-37 de
} 
cosa (pues no hay más que cosas sensibles), sino una semejanza esencial que habent suum esse per se y que causa la subsistencia de las cosas sensibles.

Sea como sea, lo propio del platonismo no es plantear la cuestión acerca de dónde están las ideas, ni mucho menos defender la existencia de formas separadas ${ }^{88}$, sino que su discusión con Aristóteles se centraba básicamente en cómo se debía entender la relación de las formas con las cosas. ${ }^{89} \mathrm{Si}$ esto en algún momento, y por circunstancias históricas comprensibles, deja de entenderse así, es fundamentalmente porque en el 529 Justiniano prohíbe la filosofía ateniense y confisca sus obras, por lo que el pensamiento platónico dejó de existir como tradición independiente pasando a ser asimilado por el pensamiento cristiano de la patrística. Y cuando los escolásticos se vuelven sobre estos temas, ya se ha desvanecido del horizonte de comprensión la problemática real entre Platón y Aristóteles, y estos autores se convierten en representantes de una discusión ajena a ellos.

El Platón que aparece en el problema de los universales en el siglo XII no es ni siquiera aquel Platón de los neoplatónicos ${ }^{90}$ más cercanos al maestro. La filosofía ya no tiene como problema esencial el del movimiento, sino que aparecen otros conceptos fundamentales que reorientan la reflexión como por ejemplo la cuestión de la nada. Aquella mismidad (to auton) y alteridad (to heterón), reposo y movimiento, unidad y pluralidad, se reinterpretan en la edad media en base a la existencia o no existencia del universal. Se va desvaneciendo el punto de vista platónico (la discusión real del platonismo), hasta que se le da una nueva forma (partiendo desde luego de algunos textos platónicos; principalmente el Timeo) separando su doctrina de los diálogos mismos y reduciendo el papel principal de la dialéctica en favor de una teoría de las ideas que la patrística había reelaborado para comprender mejor su propia fe; cumpliéndose el imperativo hegeliano de que la tara de la filosofía es aprehender su propio tiempo. ${ }^{91}$

Die Weltalter. Fragmente. In den Urfassungen von 1811 und 1813, ed. Schröter, Múnich, Beck, 1993.

${ }^{88}$ Para un estudio de la cuestión más en profundidad véase Crombie, I.M., Análisis de las doctrinas de Platón, 2 vols, Alianza, Madrid, 1979, y Ross, W.D. Teoría de las ideas de Platón, Cátedra, Madrid, 1986. Si bien la cuestión en torno a cómo se debe concebir la idea platónica es bastante plural. Para atender a las diversas concepciones de las ideas platónicas véase Zeller, E., Die philosophie der griechen in ihrer geschichtlichen Entwicklung, Tübingen-Leipzig, 1859-1868, II, 1, pp 663-672 y también Lutoslawski, W., The Origin and Growth of Plato's Logic, with an Account of Plato's Style and of the Chronology of his Writings, London, 1897, pp. 25ss. Sorprende sin embargo que ninguno de estos autores incluye a Schelling, cuya lectora de Platón defenderé más adelante.

${ }^{89}$ Siendo por ello que los sucesores del platonismo, los neoplatónicos, no se ponen a pensar dónde están las ideas universales, sino cómo puede ser que el Uno dé lugar a todo lo que hay. Su solución es la de proponer la noción de emanación. Y aún Proclo, el último gran representante neoplatónico y jefe de la escuela ateniense, quien explica aún esta relación hablando de un proceso de separación (prodos) y retorno (epistrofe).

${ }^{90}$ Muy en la línea de la lectura que se propone en este trabajo los neoplatónicos ha buscado siempre armonizar en lugar de separa las filosofías de Platón y Aristóteles

${ }^{91}$ „Das was ist zu begreifen, ist die Aufgabe der Philosophie, denn das, was ist, ist die Vernunft. Was 
Ocurre pues algo análogo a lo que ocurre con Aristóteles según anunciaba, y recogíamos, Heidegger. Quiero decir, se pierde el carácter vital del platonismo, su carácter creativo ligado a la experiencia vital del diálogo filosófico; la separación entre teoría y praxis. Dicho con la terminología heideggeriana: lo que se olvida (seguramente porque es históricamente pronto para tomar conciencia de algo semejante) es que toda idea y doctrina está relacionada con la vida, que en el caso particular de Platón significa, con el diálogo real mantenido dentro del cual todo adquiere forma.

No estamos ante una escuela de filosofía. En la Academia no se seguía el plan de estudios de la República, sino que en ella se reunían regularmente los intelectuales para dar forma a discusiones en las que, por ejemplo, se habla de aquel programa educativo de la República. Y el suelo del buen funcionamiento de esta Academia era "el hecho incuestionable de la extrema heterogeneidad de las posiciones teóricas (además de las de índole política) atribuibles a los académicos" ${ }^{\prime 92}$ respecto de su primus inter pares.

Es por eso que actualmente ya no todos buscan reconstruir el sistema filosófico del platonismo, pues se ha aceptado generalmente que "no es viable, ni metódicamente correcta, la hipótesis de un Platón sistemáticamente unitario pese a la estructura polifónica de los diálogos". ${ }^{93}$ Tenemos en la cabeza una imagen mucho menos sistemática de Platón, y más bien creativa: en lugar del defensor de una filosofía, el autor de un "gesto fundacional en el que se pone en escena por primera vez la filosofía en acción" ${ }^{94}$ Lo cual no es excluyente del reconocimiento de que efectivamente reconoceríamos cierto núcleo de teorías y un estilo filosófico específico.

Ahora bien, en la Edad Media se dieron grandes pasos en la comprensión del platonismo que no se pueden negar. Y aunque es cierto que algunos sostuvieron una separación extrema de los dos mundos, y esto parece chocar con el propio platonis$\mathrm{mo}^{95}$, pues un mundo separado sería incognoscible ${ }^{96}$ al menos para los hombres. ${ }^{97} \mathrm{Es}$

\footnotetext{
das Individuum betrifft, so ist es ohnehin jedes ein Sohn seiner Zeit; so ist auch de Philosophie ihre Zeit in Gedanken erfasst.“, Hegel, G.W.F., „Grundlinien der Philosophie des Rechts“, en Werke in zwanzig Bänden, ed. Moldenhauer, E. y Michel, K.M. vol. 7. Frankfurt am Main, Suhrkamp. p. 26.

92 VeGETTI, M., op. cit., 234.

${ }^{93}$ Ibid., 98.

${ }^{94}$ Ibid., 91.

${ }^{95} \mathrm{Al}$ respecto "la blancura es una forma inteligible (no visible). Cuando penetra en un objeto material (un rostro por ejemplo), su combinación con el cuerpo produce la blancura visible: una imitación perfecta de la Forma trascendente, que es el único modo en el que los objetos materiales pueden reflejarla. El rostro, que nunca fue perfectamente blanco, puede tornarse rojo al recibir (Fedón 102 d-2) Rojez en vez de Blancura. Pero la blancura, tanto "en sí" como en nosotros, será siempre ella misma y nada más" GuTHRIE, W.K.C., op. cit., p. 355. Si bien para otras alternativas o concepciones de la cuestión consúltese por ejemplo Hackforth, R., Plato's Phaedo. Introduction, translation and running commentary, Cambridge, 1952, p. 150, o también BLuck, R.S., Plato's Phaedo. Introduction, translation, notes and appendies, London, 1955, pp17ss y p. 92.

${ }^{96}$ Parm. $133 \mathrm{c}$.

${ }^{97}$ Parm., 133a-134e.
} 
cierto que se solía hablar de una revisión de su teoría madura, ${ }^{98}$ pero es mucho más plausible pensar que la "inseidad" de las ideas (o su idealidad) vienen sencillamente a combatir la multiplicidad propia del mundo sensible. ${ }^{99}$ No ver aquí el problema de la pluralidad ocurre en la Edad Media porque su horizonte de comprensión ha cambiado. Y esta "ceguera" pareció persistir hasta que Boecio en Contra eutychen distingue hábilmente entre subsistencia (lo que no tiene necesidad de accidentes para ser) y sustancia (lo que proporciona a los accidentes el subiectum). En este momento se redefinen los "predicables" de Porfirio ${ }^{100}$, ya que ahora puede haber subsistencia (la de los géneros y especies) sin que haya sustante. ${ }^{101}$

En este punto, las simplificaciones del platonismo medieval desaparecen. El nivel hermenéutico en la Edad Media da pasos que deben ser reconocidos en la comprensión del platonismo. Pues desde esta posición pueden llegar a comprender que es precisamente porque hay realidades que no son ellas mismas subsistentes, por lo que tienen sustancia. Desde esta teoría boeciana de la subsistencia encontrará apoyo en el siglo XIV la escuela porretana para recuperar el sentido causal del universal anterior a la pluralidad (universale in causando) distinguiéndose del universal en la pluralidad (desde donde nacía la interpretación del platonismo como un realismo extremo); profundamente influenciados desde luego por el neoplatonismo del pseudo Areopagita. Cuando los porretanos recurren a la noción de "reunión" (unio ${ }^{102}$ ) para expresar que el género no es ni una cosa universal participada (realismo), ni un término significando una pluralidad (nominalismo), sino una colección de individuos reunidos por una semejanza, se está diciendo que el universal no es cosa, sino (antecedido ya por Dionisio el pseudo-Areopagita) una causa anterior a la pluralidad.

Esta noción de universal que contiene en unidad lo que la pluralidad desarrolla, no designa ya una propiedad común, sino la propiedad esencial de cada individuo. La escolástica parece finalmente conseguir redirigir la reflexión hacia una mejor comprensión de la problemática originaria del platonismo poniendo en juego justamente esa gran capacidad hermenéutica de la que son creadores. Y sin embargo,

\footnotetext{
${ }^{98}$ Cada vez menos frecuente desde el trabajo de Rickless, S. C., Plato's Forms in Transition: A Reading of the Parmenides, Cambridge, 2007.

99 “Afirmamos que hay algo bello en sí y bueno en sí y, análogamente, respecto de todas aquellas cosas que postulábamos como múltiples" Rep. 507b.

${ }^{100}$ Para un análisis en profundidad de la diferencia entre los predicables en Porfirio y Aristóteles véase De Rivera, A. "Introduction”, en Porphyrius, Isagoge, Vrin, París, 1995; Burley, G., Super artem veterem Porphyrii et Aristotelis, ed. De Venise, 1497 y Marenbon, J., "Vocalism, Nominalism and the Categories"”, Vivarium, 30/1 (1992), 51-61.

${ }^{101}$ Para profundizar en la cuestión véase WARren, E.W., Porphyry the Phoenician, Isagoge, The Pontificial Institute of Medieval Studies, Toronto, 1975. CourTine, J.F. , "Note complémentaire pour l'histoire du vocabulaire de l'être", en Aubenque, P., (ed.), Concepts et catégories dans la pensée antique, Vrin, París, 1980, 33-87.

${ }^{102}$ Cfr., Compendium Logicae Porretanum, ed Ebbesen-Fredborg-Nielse, CiMAGL, 46, (1983), p. 54, 61-64, 55, 16-17.
} 
estas discusiones no desembocan finalmente en una mejor comprensión de la discusión originaria, entre otras cosas porque toda esta disputa desemboca, en triste rememoración de los orígenes, en una serie de prohibiciones fruto de relaciones de poder en el espacio universitario europeo en las que la dialéctica (la vía de la verdad) se convierte en lucha de poderes (para impedir la vía de la falsedad), y en la que los contrincantes son los mantenedores de la vía antigua y aquellos de la vía moderna; he aquí en gran parte el origen de la diferencia entre una filosofía continental (realista) y una filosofía inglesa (cercana al nominalismo de Occam). ${ }^{103}$

\section{III.2. Un platón reubicado en su propio tiempo}

Se debe culminar lo que parecía que en la Edad Media estaba a punto de gestarse: ¿es posible acaso recuperar un sentido originario a la hora de entender en qué sentido puede decir Platón que las ideas, que no son fruto del inteligir, existen "antes"? ¿Si nos lo preguntamos hoy, a voz de pronto, no diremos lo mismo que dijeron al principio los escolásticos? Si la discusión medieval debía servir para algo, era justamente para tomar conciencia de que es complejo definir la existencia de las ideas. Y ésta lejos de disminuirse se ha agrandado en la modernidad, al desaparecer el interés por esclarecer las discusiones medievales. Sin ellas de fondo es normal que acontezca la confusión y la simplificación (de la que nunca se podrá censurar a la filosofía medieval).

Hablar de la existencia de las ideas en Platón es a mi juicio hablar de la experiencia intelectual de su existencia. La misma experiencia desde luego que esa en base a la cual Descartes hablará de una experiencia indubitable. Si Platón, que lo cuestiona todo, no se atreve a cuestionar las ideas, su existencia, sino que se sorprende de su peculiar forma de ser en comparación con la multiplicidad sensible, ${ }^{104}$ es justamente por la fuerte experiencia que podemos llegar a tener todos de que tenemos ideas.

Platón no señala "dónde" existen esas ideas, si es que no tomamos el "en" del "en sí" como un topónimo: ${ }^{105}$ lo que se pregunta es más bien cómo podemos entender la relación de éstas con la multiplicidad sensible. De allí que sus distintas propuestas

\footnotetext{
${ }^{103}$ La disputa entre nominalistas y realistas ha sido muy estudiada. Por citar algunos: Courtenay, W. "The Register of the University of Paris and the Statues against the Scientia Occamica", Vivarium, 29 (1991), 13-49; Moody, E. A. "Ockham, Buridan, and Nicolas of Autrecourt: The Parisian Statutes of 1339 and 1340”, Studies in Medieval Philosophy, Science and Logic, Berkeley-Los AngelesLondon, University of California Press, 1975, 113-146; PAQUé, R., Le statut parisien des nominalistes. Recherches sur la formation du concept de réalité de la science moderne de la nature, PUF, París, 1985. ${ }^{104}$ Esto ni siquiera es idealismo: podríamos quizás decir que esta multiplicidad es el resto de cosas que nos rodean, podríamos pensarlas como un resto (un desperdicio) que queda al otro lado de la idealidad, y entonces habríamos dado el paso al idealismo de Hegel. Pero Platón no hace tal cosa, porque el mundo no es en el platonismo un obstáculo para las ideas.

${ }^{105}$ A este propósito cfr., Teoría de las ideas de Platón, op. cit., p. 101.
} 
(mímesis, metexis, koinonía o parousía) se refieran siempre a la relación entre la unidad inmutable y la multiplicidad semejante, y nunca a una cuestión de lugar. Platón lo que quiere pensar es la relación entre las ideas y las cosas, su intención es pues entender la relación como causa del cambio; de lo que de "ningún modo"106 parece existir por separado ${ }^{107}$ : ¿qué serían las cosas si no guardaran relación con las ideas? De este modo no hacemos sino "recuperar" el contexto histórico y vital de Platón: el problema del cambio que dominaba la reflexión helena, "distinto" del problema que resulta de pensar ambas dimensiones de la realidad (sensible e intelectual) por separado.

Una mala interpretación del mito de la caverna puede acabar por hacer de toda la filosofía platónica un esperpéntico realismo, ${ }^{108}$ cuando de lo que se trata es de entender que salir de la caverna significa conocer el mundo a la luz de las ideas y el Bien, o lo que es lo mismo: comprender lo ideal en el mundo imperfecto que percibimos por los sentidos. Lo que hay que abandonar -según Platón- es la consideración de que la verdad se encuentre en las opiniones y creencias propias de ese mundo aparente, pero no hay que rechazar el mundo y darle la espalda, sino verlo a la luz (el Sol) de las ideas, reconociendo lo que en él hay de ideal. Fíjense que no se trata de recuperar un Platón nietzscheano que afirma el mundo sensible, sino de separarnos de un Platón casi místico que se desentiende de todo lo que existe en pos de un mundo invisible. Conviene precisar en este caso el significado de universalidad.

En realidad, la cuestión acerca de la mala-comprensión de la filosofía de Platón en la escolástica la podemos formular de forma radical como sigue: si se obvia el significado de universal se corre el peligro de entender universal como unum in multis, ${ }^{109}$ y sabemos que para Platón las ideas son independientes de los muchos (este es el auténtico sentido del "en sí"). Si se piensa lo universal como unum in multis, entonces las ideas platónicas no son universales. ${ }^{110}$ Claro que cabría otras acepciones

\footnotetext{
${ }^{106}$ Para quienes consideren que este "ningún modo" es demasiado contundente deberán reconocer al menos que dicha separación no es una exigencia de la teoría.

${ }^{107}$ Resulta muy interesante traer a colación la siguiente reflexión de Rist de que "There is no assertion by Parmenides that philosophy is imposible without separate Platonic Forms, there is an assertion that philosophy is imposible without eidé" Rist, J.M., "Parmenides and Plato's Parmenides", Classical Quaterly 20-2 (1970), 221-229, p. 227.

${ }^{108}$ Conste que lo esperpéntico no es la consideración de que existan universales reales, sino de que cualquier idea exista realmente. Podemos pensar por ejemplo en el genoma humano como un posible ejemplo de universal real.

109 “el unum in multis no está en Platón, quien de ninguna manera dice que las ideas solamente se den en los muchos, sino que dice que más bien las ideas se dan separadas de los muchos" PoLo, L., "El logos predicamental", Cuadernos de Anuario Filosófico (Univ.de Navarra) nº 189, 2006. pp. 122-154, [texto accesible en red: http://www.iterhominis.com/03_Polo/02_Cadernos/LP/LP_07.htm]

110 "En absoluto las ideas platónicas son universales. En cuanto se mete a Platón en danza como una posible postura sobre la cuestión de los universales ya se confiesa que no se sabe qué quiere decir universal" Ibid., pp. 122-154, [texto accesible en red:
} 
de universalidad, es decir, distintos modos de pensar el unum versus alia. ${ }^{111}$ En este sentido quiero destacar no sólo la posibilidad de pensar el universale in repraesentando (un concepto que designa muchas cosas), sino al universale in causando: una causa que tiene muchos efectos. Una idea a la que la escolástica estaba, como habíamos dicho, empezando a dar una forma exquisita. Cuando se dice que Platón piensa las ideas como universales, lo que debería decir es que éstas actúan como una causa formal que tiene muchos efectos particulares. Si tenemos esto en cuenta la pregunta que antes nos parecía extrema, es decir, la pregunta por la realidad de las ideas universales, de repente se hace mucho más plausible: la causa formal es, ¿cómo no?, real (es decir, es).

Pero en Platón no era este el problema. Quizás para Aristóteles, que responde que lo predicable debe estar in multis. ${ }^{12}$ Lo platónico no es cuestionarse su realidad, sino preguntarse "cómo está entre" las cosas: y frente a la teoría de Eudoxo de que está mezclado o "entre", Platón dice que relacionado con las cosas en común-unión (desde distintas comprensiones que guardaban eso sí una relación de semejanza con las cosas: las ideas como las cosas, eran las que eran antes ${ }^{113}$ de que fueran pensadas; aunque ni cosas ni ideas se puedan siquiera pensar por separado ${ }^{114}$ ). Todas las formulaciones de Platón tienen en común el hecho de que ese "como" tiene un valor temporal (designan una anterioridad): lo que propone Platón son distintos modos de pensar dicha anterioridad: como una anterioridad pasada (recuerdo), como una anterioridad mantenida en las cosas (parousía y koinonía) e incluso con cierta relación al futuro cuando la piensa como imitación.

Lo que hace Aristóteles es señalar que ninguna de esas formulaciones llega a ser válida si no se aclara que las causas, que efectivamente deben estar antes del pensar, están antes pero no en sí, sino en las cosas. Por ello, Aristóteles puede introducir un doble sentido del eidos que es el que va a crear el problema escolástico en torno a las ideas universales. Lo que hace Aristóteles es, a saber: señalar un eidos que sin ser universal, ${ }_{115}$ "viene a serlo cuando la mente humana lo abstrae". ${ }^{116}$ El Eidos es así un principio formal. Pero esto está de algún modo antecedido en el Filebo de Platón, al que el estagirita lejos de criticar parece continuar. Si resumimos, espero que no demasiado, la tradición acierta a mi juicio al señalar que para Aristóteles las ideas están en la mente (propiedad lógica de la significación universal) con fundamento in re (siendo entitativamente singulares, hay sustancias primeras, anterior a las especies,

\footnotetext{
http://www.iterhominis.com/03_Polo/02_Cadernos/LP/LP_07.htm]

${ }^{111}$ Algo uno relativo a varios [C $\overline{\mathrm{fr}}$. Met., VII 13].

${ }^{112}$ Met, I 9, 991a 10.

${ }^{113} \mathrm{El}$ propio Aristóteles define la forma como lo que era antes.

${ }^{114} \mathrm{He}$ aquí el origen de la distinción metafísica que hace Aristóteles entre el ente veritativo y el ente en cuanto ente.

${ }^{115}$ Cfr., Met 7, 12.

${ }^{116}$ Introducción a Aristóteles, op. cit., 58-9.
} 
elementales e inefables ${ }^{117}$ ), pero yerra -quizás sólo en un primer momento- al considerar que el platonismo pensara las ideas "fuera" de las cosas: el en sí de Platón no significa fuera de las cosas, sino relacionadas con las cosas pero "ya" en sí; presente en las cosas de algún modo en virtud de cuya presencia la cosa es y cambia.

Propongo, llegados a este punto, continuar la tarea de aniquilamiento que inició Schelling. Dicha tarea no es un aniquilamiento del platonismo originario, ${ }^{118}$ sino del platonismo de la historia de la filosofía. Y eso aún reconociendo a Leyte que es cierto que hay cierta "kantianización" de Platón por parte del de Leonberg en función de la cual podríamos a su vez hablar de cierta deformación idealista del platonismo. ${ }^{119} \mathrm{~Pa}-$ rece sin embargo que existiría una pauta, y que nos recomendaría el propio filósofo vigués, que nos permitiría leer la lectura del Timaeus sin caer en una interpretación "idealista" 120 , a saber: no querer buscar en Platón la "llave" que cerrara ese espacio que hay entre la idea y la cosa; señalando la separación, la distancia. ${ }^{121} \mathrm{Y}$ esta pauta puede ser enunciada de otro modo: si a Schelling lo leemos desde Heidegger ${ }^{122}$ Es decir, disolviendo la añoranza de aquella supuesta identidad en la que todo se vuelve indistinguible. ${ }^{123}$

No digo que lo que sigue no sea también una lectura epocal de Platón, pues no se trata de negar la imposibilidad de escapar de las cadenas del from now here, ${ }^{124}$ sino de distinguir entre una "desvirtuación" de Platón y entre una visión epocal que llamara la atención sobre un aspecto que, estando en Platón, sin embargo ha pasado desapercibido hasta ahora precisamente porque las circunstancias históricas no lo hacía posible. Estamos ya en una época en la que debemos reconocer con cierta facilidad que no sólo existe una indudable deuda de los pensadores actuales respecto de los del pasado, sino que siempre ha existido a su vez la inversa: una deuda del pasado para con el presente, en tanto que cada presente (cada generación que diría Ortega)

\footnotetext{
${ }^{117}$ Cfr., Categorias, 2b 3-5.

118 "su Timeo liquida el de Platón, tanto bajo la burda forma platonista de diferencia entre dos mundos como bajo la refinada diferencia kantiana entre sensibilidad y entendimiento" LeYTE, A., El paso imposible, PlazayValdés, 2013, p. 175.

${ }^{119}$ Cfr., Ibid., pp. 185ss.

${ }^{120}$ Es decir, que el Timeo no reproduzca algo la concepción idealista acerca de la naturaleza y el espíritu en el Systemprogramm.

${ }^{121}$ Cfr., Ibid, p. 204.

122 "Una historia de la filosofía tendría que poder reconocer en qué sentido, más allá de la obviedad cronológica, para nosotros Schelling también viene después de Heidegger" El paso Imposible, op. cit., p 235.

123 "No esa indiferencia [que es ella misma aún una continuación de la escolástica - A.R.] a la que Schelling se ha referido en algún momento de su obra como resultado de buscar una identidad, sino esa in-di-visión que, por otra parte, es la indicación significante de eso a que nos referimos con la palabra ser cuando su significado ya no es metafísico en el sentido clásico" El paso imposible, op. cit., p 240-1. ${ }^{124}$ nuestros conceptos "se refieren a un dónde y a un cuándo, a un aquí o a un allí." Toulmin, S., Regreso a la razón. El debate entre la racionalidad y la experiencia y las prácticas personales en el mundo contemporáneo, Península, Barcelona, 2003, p. 36.
} 
está bien (y distintamente) situada para descubrir nuevas interpretaciones que desde luego se encuentran en los textos legados por la tradición.

Pero volviendo al tema: eso desapercibido a lo que me refiero en el caso de la filosofía platónica, esa "deuda de Platón para con el presente", es lo que Trías designa como la "conciencia del límite": que "porque hay límite hay tal cosa como inteligencia, razón, lógos: lingüístico, matemático o musical. Porque hay límite hay lenguaje y escritura; porque hay límite hay posible proyección de éste, en fecunda mediación de lo indeterminado y aorístico, en progresiones pitagóricas platonizantes: aritmética, geometría, estereometría, astronomía y música". ${ }^{125}$ Esta ciencia del límite es lo que a mi juicio Heidegger había encontrado en Schelling, y a lo que en otros lugares he denominado como la Potenzlose; ${ }^{126}$ siendo a su vez lo que el de Leonberg, por eso nos interesa su interpretación en este trabajo, habría encontrado en Platón al leer el Filebo.

Una interpretación no idealista de este hallazgo, sólo requeriría introducir el criterio que Leyte apuntaba, y diría algo así: el límite es, para Platón el principio de todo lo delimitado. Y nótese que aquí encontramos los números, las ideas, el decir... Trías llega a decir incluso que "el límite (peras) es, en Platón, otro modo de nombrar el Uno -la Mónada- o el Bien", ${ }^{127}$ por cuanto que si no hubiera límite el Uno subsistiría inaccesible al habla. Se entiende mucho mejor esto cuando se insiste en la importancia de la co-principialidad, en la inseparabilidad de lo determinado y lo indeterminado; que la "mezcla" es ya de algún modo el reconocimiento de que el Bien se debe dar (o lo hay; es gibt) siempre determinado.

\section{Una nueva lectura romántica de Platón}

\section{IV.1. Las claves que el siglo XX está preparada para descubrir en Platón, y la ruptura con el siglo XIX}

Es hora de romper, si lo decimos con las palabras de la escuela de Tubinga, con la hegemonía del paradigma de Schleiermacher. Pero no se trataría de desromantizar a Platón, sino de volver a romantizarlo viendo en él al promotor de un diálogo infinito y de una producción infinita, ${ }^{128}$ en la que las cosas no son finitas por ser materiales

\footnotetext{
${ }^{125}$ Trías, E. El canto de las sirenas, Galaxia Gutemberg, Barcelona, 2007, p. 863.

${ }^{126}$ Cfr., RoJAs, A., "Die Idee des Potenzlosen in der Spätphilosophie Schellings und in der spätphilosophie Heidegers" Philosophisches Jahrbuch 121, I (2014), 92-110.

${ }^{127}$ El canto de las sirenas, op. cit, p. 863.

128 "Wenn ich das Ziel erreicht habe, höre ich auf zu laufen. Diese deutsche Bedeutung von Ende hat etwa Schiller benutzt, als er fragte, zu welchem Ende man Universalgeschichte studiere. Ich habe also behauptet, daß grenzenlsoe, endlose Prozesse sinnlos sind. Wenn wir Menschen uns in diesen verfangen, sind und werden wir nicht frei“, una frase que se materializó en la siguiente formulación: „Wenn man aber nicht begreift, daß das wahre Ende Freiheit ist, wird man kein Ende wollen und in grenzenlo-
} 
(hule), sino por ser emplazadas, recogidas, recibidas y albergadas (Chora). Estaríamos aquí ante una nueva interpretación de la cuestión topológica. ${ }^{129}$

El paradigma neoplatónico de compresión del platonismo se había debilitado mucho $^{130}$. Y así, aún cuando en el siglo Xv seguía pensando Ficino que Plotino era el intérprete por excelencia de Platón, ${ }^{131}$ el intento de conciliación de las fuentes neoplatónicas con las doctrinas cristianas implicaba, por un lado, reducciones del neoplatonismo y, por otro lado -y a mi juicio lo más grave- el intento de encontrar la unidad doctrinal del platonismo. Cuando más tarde Schleiermacher publica la Platons Werke ${ }^{132}$ realiza una introducción en la que propone una nueva imagen de Platón a la altura del siglo xIx: introduce ideas como la de una evolución de la doctrina, identifica la forma artística con el contenido, busca la sistematización, intenta ser científico plegándose a los textos... Este paradigma interpretativo permanece vigente hasta que Möllendorff reivindica la autenticidad de la Carta VII. ${ }^{133}$ Lo cual ocurre en 1919, introduciendo una inestabilidad con la que se inicia la lectura platónica del siglo $X X$, y que tomará forma en la Escuela de Tubinga al reivindicar la importancia de las doctrinas no escritas. Y aunque es cierto que Nietzsche ya se había adelantado a todo este proceso señalando la importancia de lo no-escrito y no-dicho a partir del Fedro, ${ }^{134}$ considero sin embargo que esta es la situación hermenéutica propia del siglo $x X$.

\footnotetext{
se, ziellose Prozesse kommen. Aber nicht dort, sondern im Ende, im $\tau \dot{\varepsilon} \lambda$ os ist Freiheit." JACOBS W.G., „Philebos - der Kern platonischer Weisheit. Zum Problem der Endlichkeit in Schellings Philosophie.“, en Galland-Szymkowiak (eds.), Das Problem der Endlichkeit in der Philosophie Schellings. Le problème de la finitude dans la philosophie de Schelling, Berlin Zürich 2011, 333-352, p. 351s. Romantizar a Platón, a mi juicio, pasa por entender que esta misma noción de "grenzenlose, ziellose Prozesse" funcionaba en el proceso dialéctico, cuya meta no era tanto llegar a un final, sino que el proceso mismo era la auténtica finalidad, en tanto que salir de la caverna y ver de un modo directo las verdades era más bien un horizonte que dotaba de sentido aquel proceso, pero que en última instancia, como revelan los últimos diálogos, incluso los más sabios deben esforzarse por revisar sus ideas buscando lo que al principio de este trabajo designamos cono "lo falso", convirtiéndose la dialéctica en un método que no se puede abandonar nunca, y no por una limitación metodológica, sino porque no hay mayor aval que nos asegure que no hemos escapado de una caverna para entrar en otra más luminosa, que tomar conciencia de que la dialéctica se ha convertido en el lugar de llegada definitiva del hombre libre.

${ }^{129}$ Cfr., Pérez-Borbujo, F., La otra orilla de la belleza, Herder, Barcelona, 2005, pp. 389ss.

${ }^{130}$ Afortunadamente recuperado por autores como WaHL, J., Étude sur le Parménide de Platon, Vrin, Paris, 1920. P.43. y Wundt, M., Platons Parmenides, Kohlhammer, Stuttgart-Berlin, 1953, p. 26.

${ }^{131}$ Cfr., Ficino, M., "Exhortatio ad auditores in lectionem Plotini", en Opera omnia, Basilea, II, 1576, p. 1548.

${ }^{132}$ Schleiermacher, F., Platons Werke, Berlín 1804-1828.

${ }^{133}$ Cfr., Moellendorf, U., Platon. Sein Leben und seine Werke, Berlín, 1919.

${ }^{134}$ Cfr., Nietzsche, F., „Vorträge, Schriften und Vorlesungen 1871-76“, en Gesammelte Werke, IV, Múnich, p. 370.
} 
Con la escuela de Tubinga comienza pues un paradigma nuevo, que se adentra en lo misterioso y lo no dicho en búsqueda de un Platón original y "lleno de vida" 135 , que incluso debía ser salvado del intento neoplatónico de conjugarlo con el aristotelismo. Estaríamos sin embargo, a mi juicio, en un tiempo de transición. Yo quiero defender desde una perspectiva hermenéutica que la investigación no puede ir en la línea de restaurar a un Platón original e incontaminado (incluso de sí mismo al parecer, pues se trata de no dejarse engañar si quiera por sus diálogos escritos). La idea debe ser más bien intentar encontrar en esos diálogos una enseñanza genuinamente platónica y a la altura ${ }^{136}$ que nuestro tiempo nos haya permitido acceder. Esta enseñanza, más allá de la inexistente obra unitaria y pensamiento acabado de Platón, debe estar en todo lo que sea de procedencia platónica; debe estar en el neoplatonismo y debe estar también en Aristóteles; en la Edad Media y en Schleiermacher.

Eso platónico a lo que me refiero es lo siguiente: que "el movimiento escalonado y progresivo del alma se dirige en dirección a un futuro que interviene como telos: finalidad del propio deseo, eros, motor anímico siempre anhelante, en puja y porfía tras la Belleza. Esta finalidad no es la fusión con la Belleza; menos aún su disolución en ella." ${ }^{137}$ Si tiene sentido fijarse en aquel Platón invisible y esotérico es sobre todo para reconocer que había descubierto el carácter axiológico y "veritativo" del límite.

\section{IV.2. Las calves del siglo XXI está preparada para descubrir en Platón}

Si aceptamos la tarea de leer a Platón desde hoy (donde hoy significa aquí desde un Schelling leído desde Heidegger), entendiendo que no se trata de modernizar la lectura de Platón desde Schelling (por ejemplo reivindicando una definición moderna de la materia), sino de insistir en la importancia decisiva que Platón mismo había descubierto de que la Unidad (la Forma) "se determine por mediación del límite". ${ }^{138}$ Estaríamos así ante una suerte de "re-romantización"139 de Platón, para ver en él no

\footnotetext{
${ }^{135}$ Dice Platón en el Fedro, justo después de arremeter contra la escritura en el Fedro 274e-d, que existe un discurso "lleno de vida" y de alma que es el que posee el que sabe, y del que el escrito es sólo un reflejo. Cfr., Fedro 276a-b.

${ }^{136}$ Hay que aclarar que altura no significa necesariamente una "mejor" comprensión de Platón, en tanto que hay que comprender esta altura desde el perspectivismo orteguiano, quiero decir, desde la consideración de que no existe la "mejor" comprensión de Platón, sino puntos de vista distintos sobre un mismo tema. No se debe buscar "la mejor comprensión de Platón, sino de entender a Platón a la altura de nuestro tiempo. Y aquí conviene insistir en que no se trata de reinterpretar a Platón como si éste fuera un filósofo del siglo XXI (eso sería justamente contrario a la conciencia histórica), sino de intentar observar desde nuestra situación, desde el siglo XXI, qué queda por descubrir de ese platón histórico y que el paisaje de otras épocas con sus circunstancias propias nos había impedido ver.

${ }^{137}$ El canto de las sirenas op. cit, p. 832.

${ }^{138}$ Ibid., p. 839.

${ }^{139}$ Seguramente porque estoy convencido de que después de cierta crisis en la filosofía debe renacer un nuevo romanticismo a la altura del siglo XXI.
} 
una teoría en evolución, sino para ver en él al promotor de un diálogo infinito y de una producción infinita, en la que las cosas no son finitas por ser materiales (hule), sino por ser recogidas y albergadas (Chora). O dicho con otras palabras, propongo recoger el testigo de Schelling para reivindicar la filosofía de Platón como "ciencia del límite"; 140 aunque para que esto se pueda hacer notar, tengamos que leer a su vez a Schelling desde Heidegger y hacer dar a la filosofía, recupero el título del libro de Leyte, un paso imposible.

\section{El paso imposible hacia la idea de Bien}

\section{V.1. El ser limitrofe y el tiempo}

Las ideas pueden estar en muchas partes, pero en cualquier caso estaban ya antes de que las pensáramos. ¿Qué tipo de existencia es esa que hace referencia a una anterioridad semejante? En el siglo Xxi nos resulta ya complejo pensar en algo así como esencias subsistentes, ${ }^{141}$ porque no somos capaces de ponernos en posición de entender algo que existe antes que la verdad y, en consecuencia, antes que lo pensado.

Desde Aristóteles, pasando por Kant, pare entender el ser hemos tenido en primer lugar que aclararnos con el tiempo. No hablamos desde luego del tiempo físico del antes-después, sino de otro tipo de tiempo -extático lo llama Heidegger- que determina la comparecencia del ser. Precisamente porque a Heidegger le preocupaba pensar el Ser en relación con el Tiempo encuentra en Schelling la clave que necesita su propuesta filosófica para dejar de ser una hermenéutica de la facticidad (antropología) y convertirse en una filosofía de la historia (que es historia del ser). Frente al eterno retorno de Nietzsche, el tiempo sin dirección encuentra en Schelling un tiempo que, oponiéndose igualmente a todo lo lineal y duradero, se explica a partir de un fundamento (o si acaso un infundamento; el Abgrund) en virtud del cual se produce aquel movimiento constante. A saber, la importancia del límite, sin cuya fuerza, nada podría pensarse, ser, ni decirse. Y donde Schelling encontró esto seguramente por vez primera fue en el Filebo de Platón, proponiendo una lectura que, tomando las precauciones adecuadas y ya establecidas para impedir una lectura idealista de Platón, mostraba a un filósofo que no daba vueltas al problema de dónde existían las ideas, sino a qué tipo de existencias se ajustaba aquello que estaba antes del pensar, pero que sólo eran accesibles sin embargo justamente a ese pensar, del mismo modo que el mundo sensible también estaba ahí antes, pero sólo era accesible a través de los sentidos.

\footnotetext{
${ }^{140}$ Ibid., 861.

141 "las dificultades indicadas hacen preferible la formulación de Aristóteles, que además de eliminarlas, indica un pensamiento más riguroso, y un avance neto en la formulación conceptual y proposicional de la physis" Polo, L., Teoría del Conocimiento II, EUNSA, 1985, p. 335.
} 
La importancia del tiempo se había olvidado en la filosofía sobre el ser, dice Heidegger, y hay que restituirla. También para comprender bien la posición de Platón sobre el ser, pues la pregunta principal no parece ser otra que: si la verdad y el Bien estaban ya antes de que yo me pusiera a pensar, entonces iestán antes que la Inteligencia? Se puede observar por su parte que lo que quiso hacer el neoplatonismo, que conocía la crítica aristotélica, era precisamente resolver esta cuestión temporal: ¿cómo pensar aquella anterioridad de lo que es Uno? ${ }^{142}$ Parece evidente que la causa de la verdad debe ser anterior a la verdad misma, pero eso abre el problema de qué pueda significar conocer algo que es anterior a la verdad (y a cualquier cosa existen$\left.\mathrm{te}^{143}\right)$. Hay que recuperar esta dimensión temporal del Bien al leer a Platón. ${ }^{144}$

Dicho en pocas palabras: el problema que tiene Platón para explicar la relación entre las ideas y la multiplicidad sensible, para entender el cómo se relacionan (su semejanza) es un problema que no deriva del hecho de que las ideas estén "fuera" de las cosas sensibles, sino del hecho de que las ideas están "antes" del pensar ("como" las cosas). Quiero intentar brevemente y a continuación mostrarles cómo es posible entender el platonismo sin necesidad de separar las ideas de las cosas, sino entendiendo que el problema de fondo es que las ideas pueden estar antes en relación con las cosas pero "en sí", es decir antes de que se las piense. Si este es el problema del platonismo, se entiende perfectamente la solución de Eudoxo: mezcladas con las cosas; que no es esa la solución platónica, entre otras cosas, porque Aristóteles demolió esta posibilidad, junto con todas las que Platón había dado anteriormente.

Sin embargo, el problema de la solución de Eudoxo parece ser que fue sólo que no entendió bien la idea de mezcla. En el Filebo Platón va a recuperar la idea de mezcla que había utilizado Eudoxo, en un gesto que vuelve una vez más a demostrar hasta qué punto el Filebo es una respuesta relacionada con aquella discusión. Pero Platón la va a pensar de distinta manera, no ya como la mezcla de ideas en sí con las cosas, no como la mezcla de lo que está entremezclado, sino que mezcla tiene aquí el sentido de combinación. La química moderna distingue también entre mezcla y combinación para matizar la diferencia entre la que es arbitraria y la que resulta de una ley. Pues bien, esta es la novedad del Filebo, haber hecho hincapié en los principios

\footnotetext{
${ }^{142}$ La segunda hipóstasis y el primer grado de descenso del Uno a la multiplicidad. Cfr., Enn. III 8,10; $\mathrm{V} 1,7 ; 4,1$.

${ }^{143}$ Enn., III 8,8.

${ }^{144}$ De entre las 5 dificultades que comenta Polo en su Teoría del conocimiento con respecto al platonismo, os propongo la siguiente reunificación algo simplificada del problema de fondo, en el que se observa, aunque para criticar el platonismo, que se utiliza también un enfoque temporal: si la razón última es el Bien, el "bonear" ¿se identifica el Bien con la verdad o es anterior a la verdad (y a la falsedad)? (cfr. Teoría del Conocimiento II op. cit., p. 332). Parece que deberíamos decir que es anterior, pero entonces ¿cómo se conoce lo que existe antes que la verdad y, en consecuencia, antes que lo pensado? En esta reformulación de la pregunta, se ha eludido toda cuestión de lugar, y se ha expuesto la cuestión como un problema temporal.
} 
de la combinación para proponer que las ideas están combinadas con las cosas, y ello siguiendo cuatro principios o géneros que se corresponden con lo que después serán las cuatro causas aristotélicas. ${ }^{145} \mathrm{El}$ encargado de realizar dicha combinación es el Demiurgo, ${ }^{146}$ que como acabo de decir no actúa -para enojo de los voluntaristas que estaban esperando su turno en la historia de la filosofia- de manera arbitraria, sino que se trata de una combinación que debe hacer Bien, y esto significa según ciertos principios que dan razón de porqué las cosas no son como deben ser.

Las cosas no son como deben ser, y por eso hay una multiplicidad en el mundo sensible que le es ajena el mundo de las ideas. Quiero decir: muchos caballos, muchos hombres, muchos ríos... cuando en el mundo de las ideas lo que tenemos es una idea de caballo, una idea de hombre, una idea de río... La cuestión de porqué las cosas no son como deben es una pregunta pues por la multiplicidad. Ni siquiera Hegel acierta con la cuestión al considerar que la finalidad de la dialéctica consiste en salvar esa imperfección que la naturaleza añade disolviendo la multiplicidad, reuniéndola en una unidad. Schelling recupera el sentido genuino del platonismo, tal es la tesis al menos que aquí se está defendiendo, al afirmar la multiplicidad como un co-principio: esta multiplicidad es buena precisamente porque, no siendo las cosas como debieran ser, son (en lugar de deber ser) y además puede haber vida y dinamismo gracias a ese límite infranqueable.

Frente al eterno reposo que nos promete el espíritu absoluto libre de imperfecciones, en Platón hay una ausencia total de esta aspiración: lo malo sería una multiplicidad sin medida (Gorgias), o donde la medida fuera el hombre (Protágoras) en lugar del Bien, ya que entonces no habría salida de la caverna. Pero allí donde hay una ley (un lógos, dice el discípulo de Crátilo, discípulo a su vez de Heráclito), hay una buena razón para que las ideas no estén separadas de lo sensible, para que la unidad sea unidad en la multiplicidad (relación mundo inteligible y mundo sensible) y no sólo una unidad múltiple (muchas ideas).

Si tomamos sólo el nous, el Herrschaft des Nous que diría Schelling entonces es imposible comprender este asunto. Dice Krings que el Nous no puede ser pensado como el único principio de las cosas. ${ }^{147}$ No podemos pensarlo como una causa en solitario e independiente, sino siempre en relación con otro principio que Schelling define como "Princip der Verändrungen in der Welt überhaupt". ${ }^{148}$ Este principio también es traducido por Schelling con base en el Tim. 47 e4 como die Wirkungen der Vernunft. Esto no es otra cosa, dice Schelling, que la Urmaterie. Es el Worin, el

\footnotetext{
${ }^{145}$ Cfr., "De la Transformation der Philosophie y la recuperación de una comprensión del consenso ligada a la experiencia originaria del diálogo filosófico" op. cit., p. 53.

${ }^{146}$ Cfr., Timeo 68 d 4-7.

147 "Der Nous, rein und ewig unveränderlich, kann nicht als Ursache gedacht werden” KRINGS H., „Genesis und Materie -Zur Bedeutung der Timaeus-Handschrift für Schellings Naturphilosophie“, 115156, in Schelling, F.W.J., Timaeus (1794), Stuttgart-Bad Cannstatt: frommann-holzboog, 1994, p. 128. ${ }^{148}$ Timaeus (1974), op. cit., p. 29.
} 
Substrat, la Chora (Tim. 52 b1). El mundo es así un juego de fuerzas y de oposición (y la filosofía de Platón heraclítea antes que parmenídea).

El mundo ya no puede ser sólo un producto que tiene por origen las ideas. $\mathrm{Ni}$ la meta es crear una copia triste de algo mucho mejor, sino que a Platón debemos leerlo a la inversa: el destino del mundo es ser mejor que la eternidad triste de las ideas, frente a la cual el Demiurgo "quiere" hacer un mundo dinámico y vivo. Y eso sólo puede hacerse mezclando las ideas con la materia, ${ }^{149}$ no según el intento mal enfocado de Eudoxo, sino haciendo intervenir a dos principios gracias a los cuales puede llegar a concretizarse la universalidad en lo determinado afirmándose el "ser limítrofe", ${ }^{150}$ que es el único ser que hay. ${ }^{151}$ Tal es la respuesta de Platón en el Filebo al entender los principios de la imperfección y el sentido positivo del movimiento.

\section{1.2. Conclusión}

Dicho en pocas palabras la conclusión es la siguiente: las ideas están antes como las cosas, y en sí en las cosas, pero no como cosas relacionadas con cosas, sino como un compuesto bien hecho. Es este el contexto desde el que se re-ilumina la cuestión por el Bien, que el propio Platón había aplazado en la República para retomar en el Filebo.

En la unidad primigenia, lo que falta es vida, dinamismo, multiplicidad, diversidad, disputa, conflicto... todo lo que merece la pena está después del Uno, y ese uno simplemente es el principio de la mezcla, que de tal modo es (no fruto del azar, sino del Bien). No el bien de alguien que lo ha pensado (pongamos el Dios de Leibniz), sino un bien ontológico: lo platónico es afirmar que lo indiviso tiende a multiplicarse, dividirse, expandirse, desarrollarse... porque es lo bueno. No a dividirse de tal forma que en este proceso de "emanación" se pierda lo bueno o se diluya, sino que lo bueno actúa siempre impidiendo que cese la dinámica división y la multiplicidad. Porque ella no es una pérdida que lamentar, sino una ganancia y una conquista.

Y así, cuando Platón intenta comprender la relación que hay entre las ideas y las cosas, cuando se esfuerza por comprender la imperfección de estas en comparación con aquellas que nos dicen claramente cómo las cosas deberían ser y no son, lo que encuentra Platón es que es bueno que se produzca esta ruptura: es bueno que las cosas no sean como debieran ser. No es una bondad moral, sino ontológica: la multiplicidad y la imperfección son buenas ontológicamente.

\footnotetext{
${ }^{149}$ La materia es ese Grund von Existenz (SW VII 357) del Freiheitsschrift y el Vergangenheit de Die Weltalter.

${ }^{150}$ La otra orilla de la belleza, op. cit, p. 381.

151 "El límite nos da la clave para la comprensión del ser, de un ser en falta, en devenir, un ser que porfía ser, un ser histórico. Este ser es un ser dinámico, no estático, que deviene. En la entraña de este ser inquieto, expulsado de su matriz, se encuentra el nacimiento de la temporalidad y la espacialidad", ibid., 381.
} 
Entender esto con radicalidad permite explicar la mala-comprensión del platonismo en la patrística y la escolástica, más preocupada por entender hacia dónde vamos y por qué hay muerte (y no ser) que por qué hay principio (o lo que es lo mismo, algo en lugar de nada; que es el punto de vista inverso adoptado por Heidegger y Schelling). Así mismo, una idea "real" en el sentido del realismo extremo es negativo para Platón, porque tan importante como la Forma debida (y no completamente lograda) está el principio de indeterminación que actúa impidiendo su cumplimiento. Ese al que Schelling define como Materia Originaria al apoyarse en la posterior Chora del Timeo. Tal es la situación hermenéutica desde la que el siglo XxI puede leer la filosofía platónica y percatarse al fin, frente a la lectura de Platón que hemos recibido, que el ateniense no sería menos crítico que Aristóteles respecto de aquel realismo extremo al que se lo asoció en la escolástica. La diferencia entre ambos clásicos, y diré decisiva, es más bien no haber entendido que no hacía falta recurrir a un Demiurgo que aplicara los principios "sobre" las cosas, porque los principios están actuando ya "en" las cosas. ${ }^{152}$ Por eso el Dios aristotélico no se dedica a estos menesteres, sino que se limita a pensarse a sí mismo. ${ }^{153}$

Alejandro, ROJAS JIMÉNEZ

Colegio MIT School Malaga

Alejandro@filosofiaenmalaga.net

${ }_{152}$ Cfr., Arana, J., Los sótanos del universo, Biblioteca Nueva, Madrid, pp. 309ss.

${ }^{153}$ Cfr., Met., A 7 1072b 18.24. 